\title{
Lymphomatoid granulomatosis - a report on four cases: evidence for B phenotype of the tumoral cells
}

\author{
Ph. Tanière*, F. Thivolet-Béjui+, D. Vitrey+, S. Isaac ${ }^{\star}$ R. Loire\#, J.F. Cordier», F. Berger*
}

\begin{abstract}
Lymphomatoid granulomatosis - a report on four cases: evidence for B phenotype of the tumoral cells. Ph. Tanière, F. Thivolet-Béjui, D. Vitrey, S. Isaac, R. Loire, J.F. Cordier, F. Berger. (CERS Journals Ltd 1998.

ABSTRACT: Four cases of lymphomatoid granulomatosis are reported, three of them involving the lung. Histological features included a true angiocentric and angiodestructive polymorphic cellular proliferation. This included histiocytes, plasma cells, many reactive T-cells and rare large, atypical cells which were of the $B$ phenotype. Epstein-Barr virus was detected in the atypical cells by in situ hybridization in three cases, with expression of both latent membrane proteins (LMP)-1 and EpsteinBarr nuclear antigen-2 in two cases and expression of only LMP-1 in the third case.

Expression of both of these proteins suggests a defect in the T-cell-mediated immunity and that Epstein-Barr virus is not only a silent passenger but may also be involved in the pathogenesis of the disease. This could have implications for therapy. Eur Respir J 1998; 12: 102-106.
\end{abstract}

Laboratoires *d'Anatomie Pathologique de l'Hôpital E. Herriot, +de l'Hôpital de la Croix Rousse, $¥$ du Centre Hospitalier LyonSud, \#de l'Hôpital Cardio-vasculaire et Pneumologique Louis Pradel and \$Service de Pneumologie, Hôpital Cardio-vasculaire et Pneumologique Louis Pradel, Lyon, France.

Correspondence: F. Berger, Laboratoire Central d'Anatomie Pathologique, Bat 10, Hôpital E Herriot, 1, place d'Arsonval, 69437 Lyon Cedex 03, France

Fax: 33472116891

Keywords: Angiocentric lymphoma, angioimmunoproliferative lesion, Epstein-Barr nuclear antigen-2, Epstein-Barr virus, latent membrane protein, lymphomatoid granulomatosis

Received: January 301998

Accepted after revision April 181998

Supported in part by PHRC (1993 004 and 1993-005) and La Ligue contre le Cancer (Comité de la Drôme).
Lymphomatoid granulomatosis (LYG) was separated from Wegener's granulomatosis by LIEBOw et al. [1] in 1972. It was described as a lesion predominantly involving the lungs, but also affecting other extranodal sites, such as the upper respiratory tract, skin, kidneys and the peripheral and central nervous systems, and characterized by a polymorphic cellular infiltrate composed of lymphocytes, histiocytes, a few plasma cells and a varying number of medium-sized or large atypical cells. It is now well established that most cases of LYG represent a true neoplastic affection.

In 1984, JAFFE [2] coined the term "angioimmuno- proliferative lesions" (AIL) to designate both LYG and polymorphic reticulosis because of their clinical and histological similarities. A grading system based on the number of atypical cells was then established [3]. Subsequent studies, using frozen-section immunostaining techniques, identified a majority of cells as T-cells, leading to the belief that AIL was a T-cell process, but a clonal rearrangement of T-cell receptor was seldom found [4-7]. More recently, several clinical and immunohistochemical studies [8-11] using sections from formalin-fixed, paraffin-embedded blocks showed that most LYG were, in fact, B-cell neoplasias with a frequent monoclonal pattern of immunoglobulin heavy or light chains. During the same period, several studies of polymorphic reticulosis and angiocentric nasal lymphomas were published [12-15], showing that the neoplastic cells have a peculiar T-cell phenotype with a frequent expression of CD56. Molecular studies rarely detected a clonal T-cell receptor gene rear- rangement. It is now well established that LYG and angiocentric T-cell lymphomas of the upper respiratory tract are two distinct disorders.

The link between LYG to Epstein-Barr virus (EBV) is well known [7, 16, 17]. Most recent studies detected it only in B-cells [8-11].

The present study concerns four cases of LYG. The phenotype of the tumoral cells was analysed, using in situ hybridization to detect the presence of EBV and immunohistochemistry to analyse the expression of latent membrane proteins (LMP)-1 and Epstein-Barr nuclear antigen (EBNA)-2.

\section{Materials and methods}

\section{Case selection}

Eight cases diagnosed as LYG were found in the files of the Department of Pathology of Hospices Civils de Lyon. Representative haematoxylin, saffron and eosin-stained sections were reviewed by five pathologists $(\mathrm{Ph}$. Tanière, F. Thivolet-Béjui, D. Vitrey, R. Loire, F. Berger), using a multiheaded microscope.

The diagnostic criteria included a polymorphic cellular infiltrate comprising lymphocytes, histiocytes, plasma cells and varying numbers of atypical lymphoid cells, with angiocentric and angiodestructive features. Cases with a monotonous population of atypical lymphoid cells were excluded from the study. 
Table 1. - Immunostains used for analysis of paraffin sections from patients with lymphomatoid granulomatosis

\begin{tabular}{|c|c|c|c|c|}
\hline Antigen & Antibody & Supplier & Specificity & Dilution \\
\hline CD20 & L26 & Dako & B-lymphocytes & 1:100 \\
\hline CD3 & Polyclonal & Dako & T-lymphocytes & $1: 100$ \\
\hline EMA & Monoclonal & Dako & $\begin{array}{l}\text { Epithelial cells, } \\
\text { plasma cells }\end{array}$ & 1:100 \\
\hline CD68 & KP1 & Dako & Histiocytes & $1: 50$ \\
\hline CD30 & BerH2 & Dako & $\begin{array}{c}\text { Sternberg cells, } \\
\text { immunoblasts }\end{array}$ & $1: 10$ \\
\hline
\end{tabular}

\section{Immunophenotypic analysis}

Immunohistochemical stains were performed on $5 \mu \mathrm{m}$ thick sections from representative aqueous Bouin's solution-fixed, paraffin-embedded blocks of each case using a standard biotin-streptavidin (Dako, Glostrup, Denmark) method. The monoclonal antibodies used are listed in table 1 .

\section{In situ hybridization and immunohistochemistry}

The hybridization technique and the immunohistochemical reactions for CD20 and CD3 were performed on three consecutive sections for each sample. Oligonucleotides complementary to a portion of the EBV early ribonucleic acid (RNA) (EBER) were used as described previously [18] with the following modifications: the staining consisted of a first-stage incubation with a monoclonal mouse antibody to digoxigenin (Dako); after washing, a biotin-conjugated sheep antimouse goat antibody (Dako) was applied before a third stage of streptavidin-conjugated alkaline phosphatase. Finally, the antigenantibody complex was vizualized using a chromogenic peroxidase substrate solution (Dako). The slides were counterstained with haematoxylin and mounted with glycergel. The pattern of EBV latent expression was further studied in positive cases by using a monoclonal antibody to EBNA-2 (EBNA-2/R3) [19] and a cocktail of four monoclonal antibodies to LMP-1 (Dako). B-cell leukaemia-lymphoma (Bcl-2) (Dako) expression was evaluated in those cases expressing LMP-1.
Monoclonality could not be tested because: 1) no frozen material was available; and 2) the tissues had been fixed in Bouin's solution.

\section{Results}

The diagnosis of LYG was upheld in four of the eight cases reviewed. One case was excluded because insufficient tissue was available for study and three cases because they were thought to represent other entities (one pulmonary diffuse large B-cell lymphoma, one pulmonary peripheral large T-cell lymphoma and one pulmonary mucosa-associated lymphoid tissue (MALT)-B cell lymphoma of mixed low and high grade).

\section{Clinical findings}

The clinical findings of the four patients, consisting of three males and one female, are summarized in table 2.

Case 1. In 1979, a 36 yr old male presented with weight loss, skin lesions and peripheral lymphadenopathy. Laboratory investigation revealed a T-cell lymphopenia. A bilateral pulmonary infiltrate and a necrotic nodule rapidly appeared. The diagnosis of LYG was made after biopsy of a peripheral lymph node. The patient was treated with combination chemotherapy but died of the disease 18 months after the diagnosis. Autopsy revealed lesions of the lungs, spleen, liver and kidneys.

Case 2. In 1986, a $64 \mathrm{yr}$ old male was found to have a nodule in the left lower lobe during routine chest radiography. The patient was asymptomatic. A lobectomy was performed and the diagnosis of LYG was made. The patient received no adjuvant therapy. Ten months later, the pati-ent returned with intestinal obstruction. At laparotomy, a mesenteric mass was found and resected. The microscopic features were similar to those in the lung lesions. The pat-ient began combination chemotherapy. The patient was well 4 yrs later, but was then lost to follow-up.

Case 3. In 1984, a 46 yr old male presented with abdominal pain and peripheral lymphadenopathy. Radiological investigation revealed mediastinal lymphadenopathy, sple-

Table 2. - Summary of clinical findings in four patients with lymphomatoid granulomatosis

\begin{tabular}{|c|c|c|c|c|c|}
\hline $\begin{array}{l}\text { Case } \\
\text { no. }\end{array}$ & $\begin{array}{l}\text { Age } \\
\text { yrs }\end{array}$ & Sex & $\begin{array}{c}\text { Sites of } \\
\text { involvement }\end{array}$ & Treatment & Outcome \\
\hline 1 & 36 & $\mathrm{M}$ & $\begin{array}{l}\text { Lung } \\
\text { Skin } \\
\text { Lymph nodes } \\
\text { Spleen } \\
\text { Liver } \\
\text { Kidney }\end{array}$ & Chemotherapy & $\begin{array}{l}\text { Dead of disease } \\
\text { (18 months) }\end{array}$ \\
\hline 2 & 64 & M & $\begin{array}{l}\text { Lung } \\
\text { Small bowel }\end{array}$ & Chemotherapy & $\begin{array}{l}\text { Alive at } 4 \text { yrs: } \\
\text { lost to follow-up }\end{array}$ \\
\hline 3 & 46 & M & $\begin{array}{l}\text { Lymph nodes } \\
\text { CNS } \\
\text { Spleen } \\
\text { Liver }\end{array}$ & None & $\begin{array}{l}\text { Dead of disease } \\
\text { (a few weeks) }\end{array}$ \\
\hline 4 & 60 & $\mathrm{~F}$ & Lung & Chemotherapy & $\begin{array}{l}\text { Alive at } 10 \text { months } \\
\text { with local evolutive } \\
\text { disease }\end{array}$ \\
\hline
\end{tabular}

M: male; F: female; CNS: central nervous system. 
nomegaly and a cerebral lesion. There was no pulmonary lesion. Splenectomy and a surgical liver biopsy were performed. The microscopic features were those of LYG. The patient died soon afterwards. Autopsy was not permitted.

Case 4. In March 1995, a 60 yr old female presented with weight loss and asthenia. The patient had no notable past medical history. Chest radiography revealed the presence of bilateral pulmonary nodules of variable size $(0.5-5 \mathrm{~cm})$ (fig. 1). A surgical biopsy was performed. The histological features were those of LYG. No other localization of the disease was detected. The patient was started on combination chemotherapy. The patient was still alive in February 1997 with partial regression of the pulmonary nodules.

\section{Histopathological and immunohistochemical findings}

All four cases satisfied the criteria for LYG. Most cells were small lymphocytes. There were also numerous histiocytes and a few plasma cells. Interspersed with these populations were rare atypical, large cells which in some

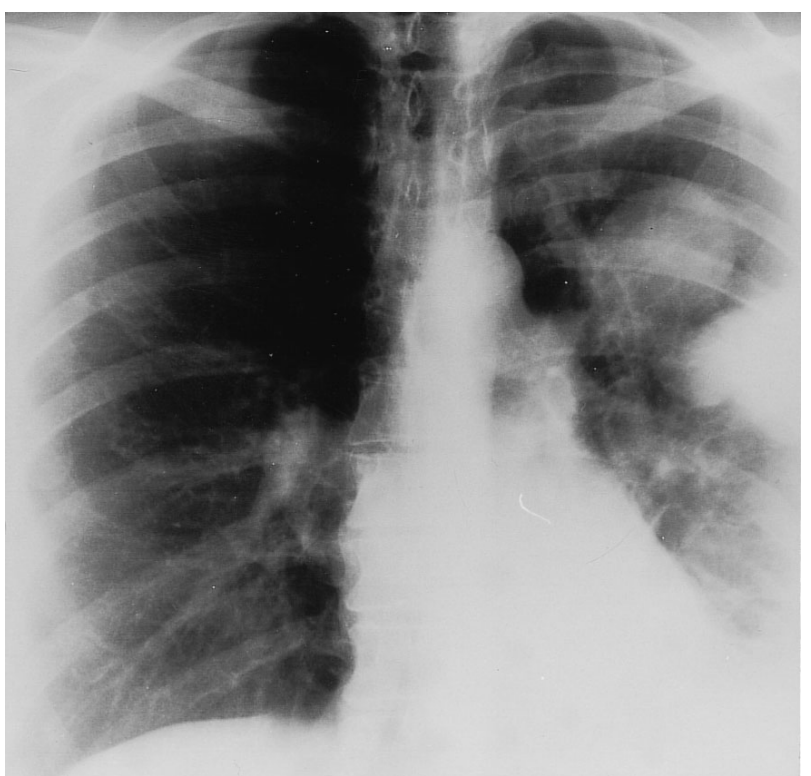

Fig. 1. - Case 4: chest radiograph showing the presence of bilateral pulmonary nodules of variable sizes $(0.5-5 \mathrm{~cm})$.

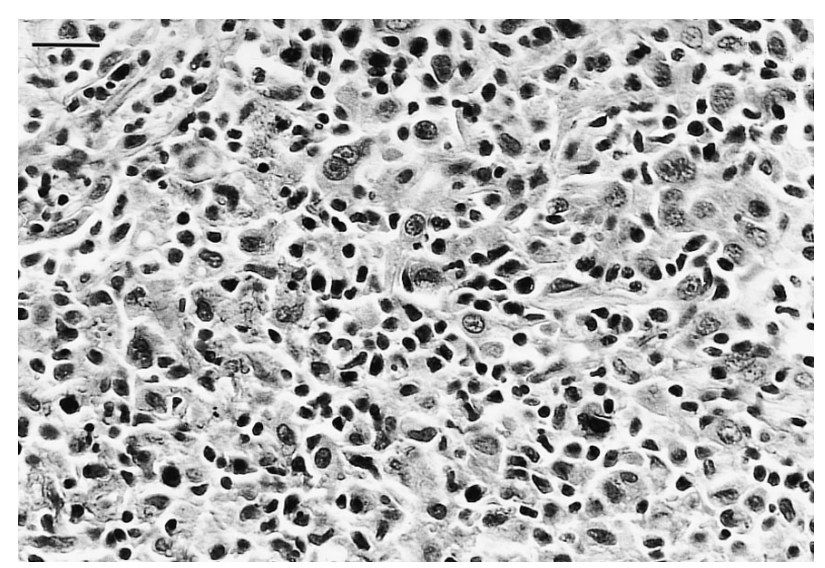

Fig. 2. - Case 4: open-lung biopsy showing granulomatous infiltrate made of normal lymphocytes, few histiocytes and rare large, atypical cells which sometimes resemble Reed-Sternberg cells (haematoxylineosin-saffron stain). (Internal scale bar $=25 \mu \mathrm{m}$ ). cases resembled Reed-Sternberg cells (fig. 2). Mitotic figures were inconspicuous. The infiltrate showed angiocentric and angiodestructive patterns with large necrotic acellular areas (figs. 3 and 4).

Most of the small lymphocytes were stained with antibody to CD3. The histiocytes stained positively with KP1. The rare atypical large cells all stained with CD20 but

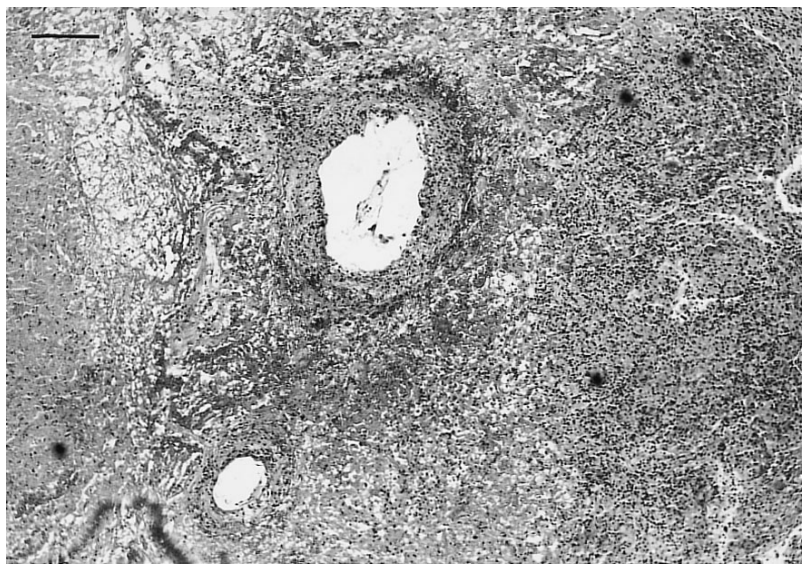

Fig. 3. - Case 1: pulmonary sample from autopsy at low magnification showing vascular involvement in a necrotic nodule with a transmural granulomatous infiltrate (haematoxylin-eosin-saffron stain). (Internal scale bar $=170 \mu \mathrm{m}$ ).

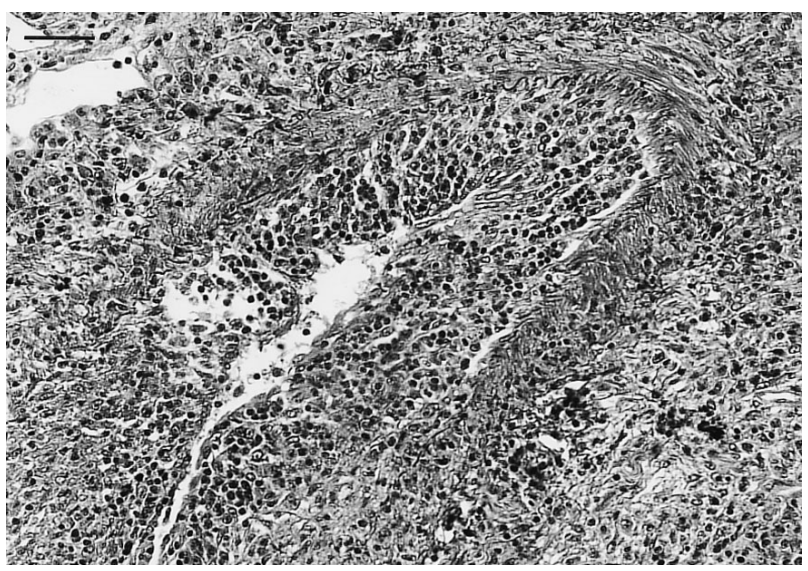

Fig. 4. - Case 4: open-lung biopsy showing transmural granulomatous infiltrate in the wall of an artery (haematoxylin-eosin-saffron stain). (Internal scale bar $=60 \mu \mathrm{m}$ ).

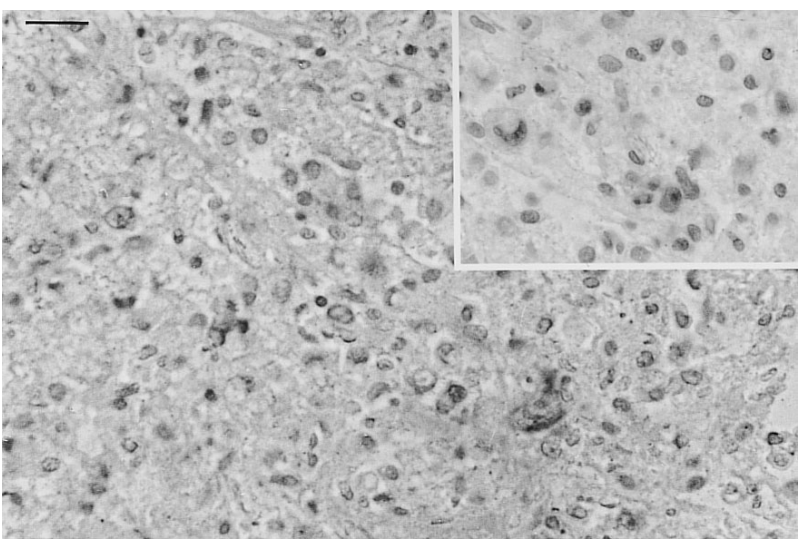

Fig. 5. - Case 1: open-lung biopsy. The large atypical B cells expressed latent membrane protein with a positive staining peroxidase-antiperoxidase method in the cytoplasm and Epstein-Barr nuclear antigen-2 (inset) with a positive staining (alkaline phosphatase procedure) in the nucleus. Counterstained with haematoxylin. (Internal scale bar $=25 \mu \mathrm{m}$ ). 
remained negative for $\mathrm{CD} 30$ and epithelial membrane antigen (EMA).

\section{Association with Epstein-Barr virus}

EBV RNA in situ hybridization showed positive cells in three of the four cases (cases 1, 2 and 4). The staining was limited to the large cells expressing CD20. LMP-1 positive staining was found in the large atypical cells in the three cases expressing EBV RNA; EBNA-2 was found in only two of these cases (cases 1 and 2) (fig. 5). Tumoral cells also expressed Bcl-2 in the three cases expressing EBV.

\section{Discussion}

The four cases of LYG reported herein were of B phenotype. This is in agreement with recent studies [8-11], based on paraffin-section immunostains. Many of the cases reported by GUINEE et al. [8] and MYeRs et al. [9] had previously been diagnosed as malignant lymphomas of T-cell phenotype, based on the evaluation of frozen-section immunostains. In fact, these techniques failed to demonstrate the presence of rare B-cells among the large number of reactive non-neoplastic T-cells because of the poor preservation of the morphology.

Several studies have demonstrated the link of LYG to EBV using polymerase chain reaction (PCR) or Southern blot analysis [7, 16, 17]. Using a double-labelling technique, some authors [8-10] recently showed the virus to be located in the large atypical cells of B-phenotype. MYeRs et al. [9] were unable to detect the virus in their three cases of T-phenotype. The double-labelling technique was not used in the present study, but the analysis of three consecutive sections revealed EBV genome in the large cells of B phenotype in three out of our four cases.

LMP-1 and EBNA-2 protein expression has not yet been studied in LYG. They are known to have oncogenic properties. LMP-1 induces the expression of the Bcl-2 gene [20,21], protecting the cells from apoptosis, and has transforming activity in fibroblasts [22]; EBNA-2 can induce the expression of numerous cellular and viral oncogenes [23-25]. Therefore, the presence of these two proteins in tumoral cells suggests that EBV is not simply a silent passenger but may play a role in the pathogenesis of the disease. They are also immunogenic proteins, inducing a T-cell-mediated reaction with destruction of the EBV-infected cells [25]. LMP-1 and EBNA-2 expression in tumoral cells is therefore related to a defect in the Tcell-mediated immune response. The combined expression of these two proteins has been detected exclusively in post-transplantation and human immunodeficiency virus (HIV)-related lymphoproliferative diseases [26]. The detection of these latent viral proteins in LYG is in agreement with the several reports of the disease occurring in the setting of immunodeficiency, such as following organ transplantation [27] or immunosuppressive therapy [28] or in acquired immunodeficiency syndrome (AIDS) patients [29-31]. Moreover, many authors have pointed out the presence of biological immune disorders in LYG such as lymphopenia, anergy, decrease in the in vitro reactivity to mitogens and antigens or inversion of the T4/T8 ratio [32-
34]. Furthermore, lymphopenia without clinical manifestations of immunodepression was noted in case 1.

Therefore, lymphomatoid granulomatosis seems to represent, in most cases, an Epstein-Barr virus-related lymphoproliferation of the B-cell lineage preferentially arising in patients with immune disorders. This could have implications in therapy. By analogy with the post-transplant lymphoproliferative diseases, it can be suggested that immunomodulation and/or antivirals should be tested. WyndHAM et al. [10] showed that three of four low-grade lymphomatoid granulomatosis cases treated with interferon- $\alpha 2 b$ were alive and disease free at 36,43 and 60 months. This needs to be confirmed by further studies but such an approach could be of great interest in low-grade lymphomatoid granulomatosis.

Acknowledgements: The authors are grateful to E. Kremmer from the Institute of Molecular Biology and Tumour Genetics, Munich, Germany, for the gift of the anti-EBNA2 antibody and to D. Clausen for correcting the English text.

\section{References}

1. Liebow AA, Carrington CR, Friedman PJ. Lymphomatoid granulomatosis. Hum Pathol 1972; 3: 457-548.

2. Jaffe ES. Pathologic and clinical spectrum of post-thymic T-cell malignancies. Cancer Invest 1984; 2: 413-426.

3. Lipford EH, Margolick JB, Longo DL, Fauci LA, Jaffe ES. Angiocentric immunoproliferative lesions: a clinicopathologic spectrum of post-thymic T-cell proliferations. Blood 1988; 72: 1674-1681.

4. Bleiweiss IJ, Strauchen JA. Lymphomatoid granulomatosis of the lung: report of a case and gene rearrangement studies. Hum Pathol 1988; 19: 1109-1122.

5. Donner LR, Dobin S, Harrington D, Bassion S, Rappaport ES, Peterson RF. Angiocentric immunoproliferative lesions (lymphomatoid granulomatosis). A cytogenetic, immunophenotypic, and genotypic study. Cancer 1990; 65: 249-254.

6. Gaulard Ph, Henni T, Marolleau JP, et al. Lethal midline granuloma (polymorphic reticulosis) and lymphomatoid granulomatosis. Cancer 1988; 62: 705-710.

7. Medeiros LJ, Peiper SC, Elwood L, Yano T, Raffeld M, Jaffe ES. Angiocentric immunoproliferative lesions: a molecular analysis of eight cases. Hum Pathol 1991; 22: $1150-1157$.

8. Guinee D, Jaffe E, Kingma D, et al. Pulmonary lymphomatoid granulomatosis. Evidence for a proliferation of Epstein-Barr virus infected B-lymphocytes with a prominent T-cell component and vasculitis. Am J Surg Pathol 1994; 18: 753-764.

9. Myers JL, Kurtin PJ, Katzenstein AL, et al. Lymphomatoid granulomatosis. Evidence of immunophenotypic diversity and relationship to Epstein-Barr virus infection. Am J Surg Pathol 1995; 19: 1300-1312.

10. Wyndham HW, Kingma DW, Raffeld M, Wittes RE, Jaffe ES. Association of lymphomatoid granulomatosis with Epstein-Barr viral infection of B lymphocytes and response to interferon- $\alpha 2 \mathrm{~b}$. Blood 1996; 87: 4531-4537.

11. Nicholson AG, Wotherspoon AC, Diss TC, et al. Lymphomatoid granulomatosis: evidence that some cases represent Epstein-Barr virus-associated B-cell lymphoma. Histopathology 1996; 29: 317-324.

12. Ho FCS, Choy D, Loke SL, et al. Polymorphic reticulosis and conventional lymphomas of the nose and upper aero- 
digestive tract: a clinicopathologic study of 70 cases, and immunophenotypic studies of 16 cases. Hum Pathol 1990; 21: 1041-1050.

13. Kanaveros P, De Bruin PC, Briere J, Meijer CJ, Gaulard $\mathrm{Ph}$. Epstein-Barr virus (EBV) in extra-nodal T-cell nonHodgkin's lymphomas (T-NHL). Identification of nasal TNHL as a distinct clinicopathological entity associated with EBV. Leukemia Lymphoma 1995; 18: 27-34.

14. Strickler JG, Meneses MF, Habermann TM, et al. Polymorphic reticulosis: a reappraisal. Hum Pathol 1994; 25: 659-665.

15. Jaffe ES, Chan JK, Frizzera G, Mori S, Feller AC, Ho FC. Report of the workshop on nasal and related extranodal angiocentric T/natural killer cell lymphomas. Am J Surg Pathol 1996; 20: 103-111.

16. Katzenstein AL, Peiper SC. Detection of Epstein-Barr virus genomes in lymphomatoid granulomatosis: analysis of 29 cases by the polymerase chain reaction technique. Mod Pathol 1990; 3: 435-441.

17. Medeiros LJ, Jaffe ES, Chen YY, Weiss LM. Localization of Epstein-Barr viral genomes in angiocentric immunoproliferative lesions. Am J Surg Pathol 1992; 16: 439-447.

18. Delecluse HJ, Kremmer E, Rouault JP, Cour C, Bornkamm G, Berger F. The expression of Epstein-Barr virus latent proteins is related to the pathological features of post-transplant lymphoproliferative disorders. Am J Pathol 1995; 146: 1113-1120.

19. Zimber Strobl U, Kremmer E, Grasser F, Marschall G, Laux G, Bornkamm GW. The Epstein-Barr virus nuclear antigen 2 interacts with an EBNA2 responsive cis-element of the terminal protein 1 gene promoter. $E M B O \mathrm{~J}$ 1993; 12: 167-175.

20. Henderson S, Rowe M, Gregory C, Wang F, Kieff E, Rickinson A. Induction of bcl-2 expression by EpsteinBarr virus latent membrane protein-1 protects infected B cells from programmed cell death. Cell 1991; 65: 11071115.

21. Rowe M, Peng-Pilon M, Huen DS, et al. Upregulation of bcl-2 by the Epstein-Barr virus latent membrane protein LMP1: a B-cell specific response that is delayed relative to NF-kB activation and to induction of cell surface markers. J Virol 1994; 68: 5602-5612.

22. Wang D, Liebowitz D, Kieff E. An EBV membrane protein expressed in immortalized lymphocytes transforms established rodent cells. Cell 1985; 43: 831-840.

23. Wang F, Gregory CD, Rowe M, et al. Epstein-Barr virus nuclear antigen 2 specifically induces expression of the
B-cell activation antigen CD23. Proc Natl Acad Sci USA 1987; 84: 3452-3456.

24. Cordier M, Calender A, Billaud M, et al. Stable transfection of Epstein-Barr virus (EBV) nuclear antigen 2 in lymphoma cells containing the EBV P3HR1 genome induces expression of B-cell activation molecules CD21 and CD23. J Virol 1990; 64: 1002-1013.

25. Rickinson AB, Murray RJ, Brooks J, Griffin H, Moss DJ, Masucci MG. T cell recognition of Epstein-Barr virus associated lymphomas. Cancer Surv 1992; 13: 53-80.

26. Rowe M, Young LS, Crocker J, Stokes H, Henderson S, Rickinson AB. Epstein-Barr virus (EBV)-associated lymphoproliferative disease in the SCID mouse model: implications for the pathogenesis of EBV-positive lymphomas in man. J Exp Med 1991; 173: 147-158.

27. Hammar SP, Mennemeyer R. Lymphomatoid granulomatosis in a renal transplant recipient. Hum Pathol 1976; 7: 111-116.

28. Troussard X, Galateau F, Gaulard Ph, et al. Lymphomatoid granulomatosis in a patient with acute myeloblastic leukemia in remission. Cancer 1990; 65: 107-101.

29. Anders KH, Latta H, Chang BS, Tomiyasu U, Quddusi AS, Vinters HV. Lymphomatoid granulomatosis and malignant lymphoma of the central nervous system in the acquired immunodeficiency syndrome. Hum Pathol 1989; 20: $326-334$.

30. Lin-Greenberg A, Villacin A, Moussa G. Lymphomatoid granulomatosis presenting as ulcerative gastrointestinal tract lesions in patients with human immunodeficiency virus infection. Arch Intern Med 1990; 150: 2581-2583.

31. Mittal K, Neri A, Feiner H, Schinella R, Alfonso F. Lymphomatoid granulomatosis in the acquired immunodeficiency syndrome. Evidence of Epstein-Barr virus infection and B-cell clonal selection without myc rearrangement. Cancer 1990; 65: 1345-1349.

32. Fauci AS, Haynes BF, Costa J, Katz P, Wolff SM. Lymphomatoid granulomatosis. Prospective clinical and therapeutic experience over 10 years. $N$ Engl J Med 1982; 306: 68-74.

33. Israel HL, Patchefsky AS, Saldana MJ. Wegener's granulomatosis, lymphomatoid granulomatosis, and benign lymphocytic angiitis and granulomatosis of lung. Recognition and treatment. Ann Intern Med 1977; 87: 691-699.

34. Katzenstein AL Carrington CB, Liebow AA. Lymphomatoid granulomatosis. A clinicopathologic study of 152 cases. Cancer 1979; 43: 360-373. 